\title{
Development of 'Itália Melhorada' grapes on different rootstocks and under the semiarid conditions of the Rio Grande do Norte State, Brazil
}

\section{Desenvolvimento da videira 'Itália Melhorada' sob diferentes porta- enxertos na Região do Semiárido Potiguar, Brasil}

\author{
Aldrin Mario da Silva Benjamin ${ }^{1}$; Débora Jesus Dantas ${ }^{2 *}$; Django Jesus Dantas 3 ; \\ Glauber Henrique de Sousa Nunes ${ }^{2}$; Celso Valdevino Pommer²; \\ Ricardo Enrique Bressan-Smith"; Vander Mendonça ${ }^{2}$
}

\begin{abstract}
Our study was carried out in the region of Mossoró city, state of Rio Grande do Norte (Brazil), in February 2013. This experiment aimed to describe the phenology, estimate biometeorological indexes, and perform a chemical characterization of 'Itália Melhorada' grapes (Vitis vinifera L.) grafted on three different rootstocks (cultivars: IAC 313, IAC572, and IAC766), during two production cycles and under semiarid conditions. The first cycle lasted 115 days, with a pruning performed on 04/19/2013; yet the second lasted 111 days, with a pruning on $09 / 25 / 2013$. In the first cycle, the thermal sum required was 1258.27 DD (degree days), while in the second, it was 1290.50 DD. The Heliothermic Geslin Index (HGI) observed in the first cycle was 352.84 and, in the second, it was 371.17. The rootstocks had no influence on the evaluated factors (phenology, TTA, TSS, and STT/ TTA) in either of the two cycles, therefore, all the tested rootstocks can be used indistinctly, but still, the analysis revealed differences from one cycle to another in terms of TSS and TSS / TTA of berries.
\end{abstract}

Key words: Grapevine. Grapes. Phenology. Biometeorological indexes. Vitis vinifera.

\section{Resumo}

O experimento foi realizado na região de Mossoró -RN, em fevereiro de 2013 com objetivo de descrever a fenologia, estimar a índices biometeorológicos e realizar a caracterização química da videira 'Itália Melhorada' (Vitis vinifera L.) sob três porta-enxertos diferentes (IAC 313, IAC572 e IAC766) em dois ciclos de produção nas condições no Semiárido. A duração do $1^{\circ}$ ciclo foi de 115 dias, com poda realizada em 19/04/2013, e de 111 dias para o $2^{\circ}$ ciclo, com poda realizada em $25 / 09 / 2013$. A soma térmica necessária no primeiro ciclo foi 1258,27 GD e no segundo foi 1290,50 GD. O índice heliotérmico de Geslin (IHG) observado para o $1^{\circ}$ ciclo foi de IHG 352,84 e para o segundo foi de IHG 371,17. Os portaenxertos não influenciaram os fatores avaliados (fenologia, ATT, SST e STT/ATT) em nenhum dos dois ciclos de produção de 'Itália Melhorada', concluindo-se que os porta-enxertos podem ser usados

\footnotetext{
${ }^{1}$ Discente, Curso de Doutorado, Programa de Pós-Graduação em Fitotecnia, Universidade Federal Rural do Semi-Árido, UFERSA, Mossoró, RN, Brasil. E-mail: aldrin.msb@gmail.com

2 Profs. Drs., Programa de Pós-Graduação em Fitotecnia, UFERSA, Mossoró, RN, Brasil. E-mail: debora.dantas@ufersa.edu.br; glauber@ufersa.edu.br; cvpommer@gmail.com; vander@ufersa.edu.br

3 Pós-Doutor, Programa de Pós-Graduação em Fitotecnia, UFERSA, Mossoró, RN, Brasil. E-mail: djdagr@hotmail.com

4 Prof. Dr., Universidade Estadual do Norte Fluminense Darcy Ribeiro, UENF, Programa de Pós-Graduação em Produção Vegetal, Campos dos Goytacazes, RJ, Brasil. E-mail: bressan@uenf.br

* Author for correspondence
} 
indistintamente, porém a análise revelou diferenças entre ciclos para SST e SST/ATT das bagas.

Palavras-chave: Videira. Uva. Fenologia. Índices biometeorológicos. Vitis vinifera.

\section{Introduction}

In recent years, the possibility of producing grapes in non-traditional regions reveals new opportunities and possibilities for expansion of viticulture in the national and international market (OLIVEIRA, 2014). These opportunities unveil new challenges for vine research in non-producing regions. Climate surveys have pointed to the viability of developing viticulture in the semi-arid region of in Rio Grande do Norte state, in Brazil (OLIVEIRA, 2014; CORREIA FILHO et al., 2010), which has generated expectations of future plantations in the coming years. This semi-arid region presents in its identity unique and striking characteristics, especially as regards the intensification of irrigated perimeters for fruit production, which, in this area, is more related to family farming, being well known by the high production of fruits, especially melons, bananas, and mangoes (SILVA; SILVA, 2006).

In viticulture worldwide, the climate is a determining factor for the adaptation of varieties, as well as in terms of productivity and quality. In Brazil, grape production is distributed from the extreme south to the northeast (POMMER, 2003). This new situation of brazilian viticulture, marked by its adaptability to climates, allows a geographical redistribution of viticulture in Brazil, especially with the increase of new producing states, such as Ceará, in the northeast (TEIXEIRA et al., 2012). According to Oliveira (2014), the results of grape quality and production in the brazilian semi-arid region arose from intense research carried out in recent years, mainly in the Petrolina-Juazeiro region, enabling the development of new management techniques for the production of new cultivars. Currently, in the northeast of Brazil, grapes have been grown successfully in the San Francisco River Valley, near Petrolina (PE) and Juazeiro (BA), in a semi-arid climate.
A natural mutation was identified in a commercial vineyard of the variety Itália ('Bicane' $\mathrm{x}$ 'Moscatel de Hamburgo') in the pole of Petrolina-PE / JuazeiroBA, where plants with better characteristics than the 'Italia' grape were found, especially due to a greater weight and size of berries, weight of bunches and a more pronounced Muscat flavor, giving it a more pleasant flavor. This variety was called 'Itália Muscat' and also 'Itália Melhorada' (LEÃO et al., 2011).

In this context, the objective of this study was to carry out the phenological and chemical characterizations of the table cultivar 'Itália Melhorada' (Vitis vinifera L.) grafted on three rootstocks [IAC 313 (Tropical), IAC 572 (Jales), and IAC 766 (Campinas)], grown in the semiarid of Rio Grande do Norte (Brazil), in addition to determining biometeorological indexes for this variety in the region.

\section{Material and Methods}

Characterization of the experimental area and plant material

The experiment was installed at the Rafael Fernandes Experimental Farm, in Federal Rural Semiarid University (UFERSA), municipality of Mossoró - RN, Brazil (5'11' S and 37 $20^{\circ}$ W, $18 \mathrm{~m}$ altitude).

According to the classification of Köppen, local climate is a BSw'h' type (very hot and semi-arid climate, a steppe-like habitat). The evaluations were carried out in plants of the variety 'Itália Melhorada', planted in February 2011, using seedlings produced by table grafting on the cultivars IAC 313 'Tropical', IAC 572 'Jales', and IAC 766 'Campinas' as rootstocks. The driving system used was a wide $\mathrm{Y}$ ( $3 \mathrm{~m} \times 2 \mathrm{~m}$ spacing) with a sprinkler irrigation system. 
To standardize budding, buds were sprayed with a 5\% Dormex ${ }^{\circledR}$ solution (v/v), immediately after pruning. In the first evaluated cycle, spur pruning was held on 04/19/2013 and, in the second, it was on $09 / 25 / 2013$. Mixed-type pruning was carried out, keeping 10 to 12 buds in canes and 3 buds in spurs.

\section{Phenology of production cycles (Pruning-Harvest)}

The phenological behavior of grapevine production cycle was determined for the period between pruning and harvesting by means of visual observations, performing two weekly evaluations from pruning to flowering and then a weekly evaluation until harvest. This characterization was performed following the phenological scale of Lorenz and Eichhorn (LORENZ et al., 1995), recording the duration of the following phases, in days: a) Pruning to Budding (PR-BU) - when 50\% of the buds reached the green tip stage, that is, leaf tissue exposure; b) Budding to flowering (BU-FL)when $50 \%$ of inflorescences reached $50 \%$ flowering; c) Flowering to fruiting (FL-FR) - when $50 \%$ of the bunches started fruit setting, that is, young growing fruit with a diameter greater than $2 \mathrm{~mm}$; d) Fruiting to maturation (FR-MT) - when $50 \%$ of the clusters had berries starting to soften and; e) Maturation to harvest (MT-HA)- when $50 \%$ of the clusters reached the harvest point, presenting soluble solids content equal to or greater than $14^{\circ}$ Brix.

\section{Chemical characterization of berries}

Total soluble solids content was obtained by refractometry, using ATAGO N1 portable refractometer, with reading within the range between 0 and $32^{\circ}$ Brix. The readings were made in juice samples of 10 berries.

Likewise, juice samples of 10 berries were used for titratable total acidity determinations. From this, a $5 \mathrm{~mL}$ aliquot was transferred to a Becker containing about $50 \mathrm{~mL}$ deionized water. Three drops of $1 \%$ phenolphthalein indicator were added to the sample, and titration was carried out under stirring with $0,1 \mathrm{~N} \mathrm{NaOH}$ solution, previously standardized with potassium biftalate until the sample changes in color. The results were expressed in gram equivalent of tartaric acid (100 g of pulp $)^{-1}$.

The ratio of total soluble solids and titratable total acidity was obtained by dividing the former to the latter. The results were expressed by means of the absolute values found.

\section{Biometeorological indexes}

Concerning the biometeorological indexes, we chose to evaluate the Degrees Days (DD) and the Heliothermic Geslin Index (HGI), in order to recognize the importance of climatic factors, such as temperature and photoperiod, to grape production and quality, besides the lack of information about this crop in the studied region.

\section{Degrees days (DD)}

To evaluate the effect of the semi-arid climate on cycle duration and quality of grapes, we decided to analyze the data obtained from the calculations of Degrees Days (DD), which are determined by the difference between the mean temperature and the base temperature (growth paralysis) during the production cycle. For that, we used the equation proposed by Vila Nova et al. (1972), described below:
a) $\mathrm{DD}=(\mathrm{Mt}-\mathrm{Bt})+(\mathrm{MT}-\mathrm{Mt}) / 2$, para $\mathrm{Mt}>\mathrm{Bt}$;
b) $\mathrm{DD}=(\mathrm{Mt}-\mathrm{Bt}) 2 / 2(\mathrm{MT}-\mathrm{Mt})$, para $\mathrm{Mt}<\mathrm{Bt}$;
c) $\mathrm{DD}=0$ para $\mathrm{Bt}>\mathrm{MT}$.

In which: DD: Degrees Days; MT: daily maximum temperature $\left({ }^{\circ} \mathrm{C}\right)$; $\mathrm{Mt}$ : daily minimum temperature $\left({ }^{\circ} \mathrm{C}\right)$; and $\mathrm{Bt}$ : base temperature $\left({ }^{\circ} \mathrm{C}\right)$.

In the present study, we considered $10^{\circ} \mathrm{C}$ as the base temperature for the entire vegetative cycle, as proposed by Pedro Júnior et al. (1994), and formula (a) was used, where $\mathrm{Mt}>\mathrm{Bt}$. 


\section{Heliothermal geslin index (HGI)}

The Heliothermic Geslin Index (HGI) was calculated by summing the product of mean air temperature and photoperiod, observed during the production cycle. The HGI was calculated according to the formula proposed by Geslin (1944):'

$H G I=\left(\frac{1}{100}\right) \times \sum($ Tmean $\mathrm{x} \mathrm{n})$

In which:

$\mathrm{T}_{\text {mean }}=$ is the mean temperature (in ${ }^{\circ} \mathrm{C}$ ) and $\mathrm{n}$ $=$ mean photoperiod (in hours) for the considered period.

\section{Experimental design}

The experiment was performed in a randomized block design (RBD) with split-plots in time and six replicates. In the plots, the rootstock factor was allocated in three levels evaluated in time (subplot) in two cycles. The data were submitted to analysis of variance (ANOVA) by the F-test, and the means were compared by the Tukey's test using the statistical software SAS ${ }^{\circledR}$ (SAS INSTITUTE, 1989).

\section{Results and Discussion}

Production phenology and the semi-arid conditions of Rio Grande do Norte

Table 1 shows a summary of the phenological phases of 'Itália Melhorada' grapes in the first and second production cycles according to the scale proposed by Eichhorn and Lorenz (LORENZ et al., 1995). As no differences were observed among the tested rootstocks in terms of sub-phase duration of all phenological stages, Table 1 presents the data of the three rootstocks (IAC 313, IAC 572 and IAC 766). One of the factors that may have contributed to this duration of similar phenological phases for 'Itália Melhorada' variety during the two cycles, independently of the used rootstock, can be explained by the application of Dormex ${ }^{\circledR}$, which induced a uniform budding in all treatments, besides of the homogeneous experimental conditions. Such conditions have favored the expression of characteristics of rootstocks, which, in this case, had no influence on the development of phenological stages in the grafted variety. However, it should be taken into account that these observations were made on young plants, only two years old, and that these results may vary with the maturity of plants. Sato et al. (2008) found that in the northern region of Paraná, rootstocks IAC 572 and IAC 766 showed no effect on the cycle length of 'Rubea' grapes ( $V$. labrusca), in the first year of production.

Although the temperature conditions between January 2013 and January 2014 showed no great variation (Figure 1), in the second cycle, the harvest was anticipated in four days when compared to the first period (Table 1). With the exception of the phenological sub-phase FR-MT (fruiting to maturation) that had a longer duration in this cycle and FL-FR (flowering to fructification) that had the same length in both cycles, all the other sub-phases in that period were lower than in the first cycle, what have contributed to harvest precocity (table 1). From the point of view of both producer and consumer, such precocity in harvest can assure the supply of this variety at this time of the year, in the local market. 
Table 1. Duration in days between the different phenological phases of the 'Itália Melhorada' grapevine in two cycles, grown under the semi-arid conditions of the state of Rio Grande do Norte, Brazil.

\begin{tabular}{|c|c|c|c|c|c|c|c|}
\hline \multirow{2}{*}{ Cycles } & \multirow{2}{*}{ Pruning } & \multicolumn{5}{|c|}{ Phenological phases } & \multirow{2}{*}{ Total } \\
\hline & & PR-BU & BU-FL & FL-FR & FR-MT & MT-HA & \\
\hline $1 \mathrm{st}$ & $19 / 04 / 2013$ & 9 & 23 & 4 & 51 & 28 & 115 \\
\hline \multirow[t]{2}{*}{ 2nd } & $25 / 09 / 2013$ & 7 & 20 & 4 & 56 & 24 & 111 \\
\hline & average & 8 & 21,5 & 4 & 53,5 & 26 & 113 \\
\hline
\end{tabular}

PR-BU (Pruning to budding); BU-FL (Budding to flowering); FL-FR (Flowering to fruiting); FR-MT (Fruiting to maturation); MT-HA (Maturation to harvest).

Figure 1. Monthly averages of maximum, mean, and minimum temperatures and photoperiod from January 2013 to January 2014. Source: UFERSA Meteorological Station / Rafael Fernandes Experimental Farm.

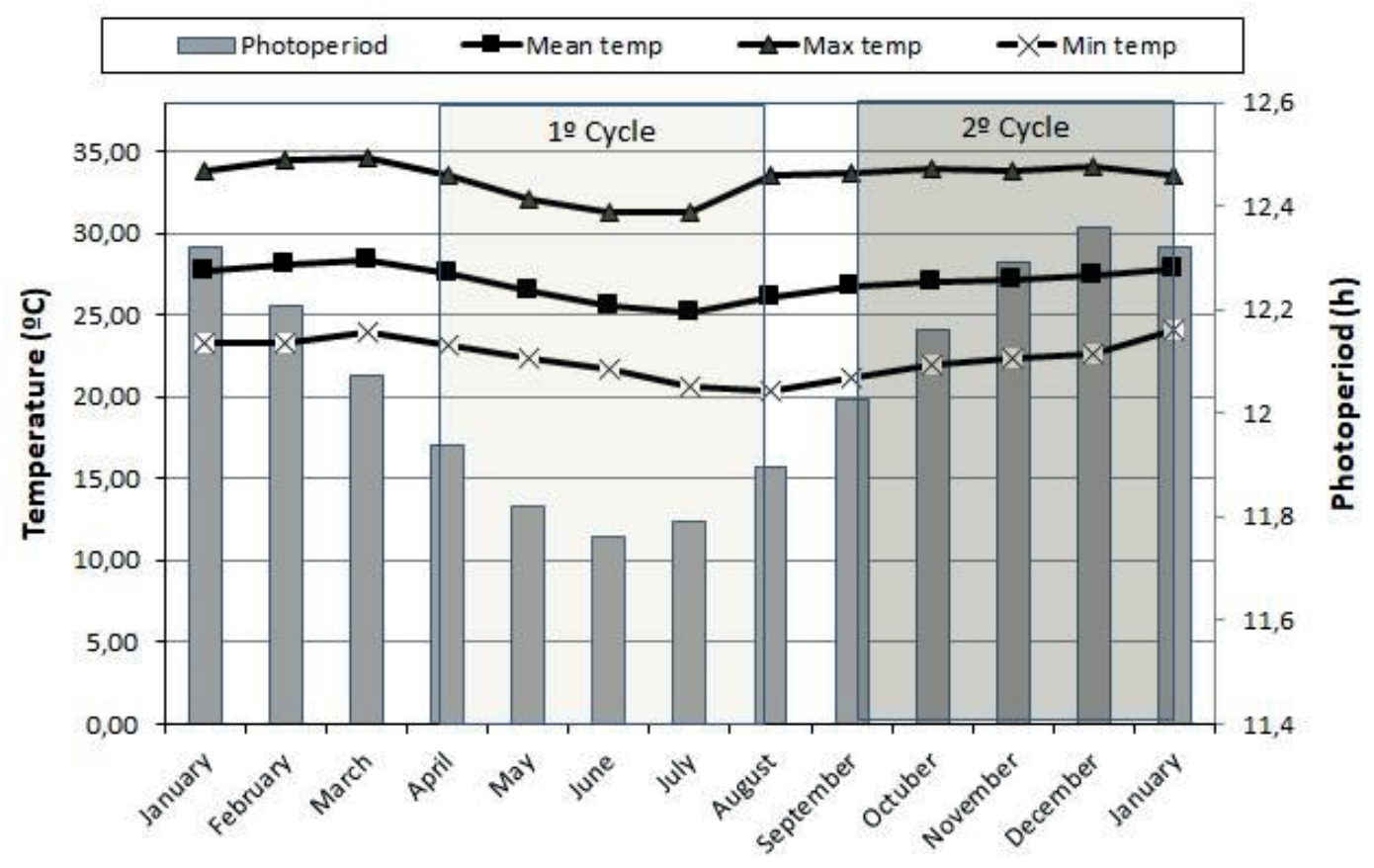

Also studying 'Itália Melhorada' but grown in the lower São Francisco Valley, Leão et al. (2011) observed a similar duration of the phenological cycle as in the western Rio Grande do Norte, which lasted between 115 and 112 days, in the first and second semester respectively. As it was said, the FR-MT period was longer in the second cycle. These results may suggest that despite an additional irrigation, the low rainfall registered during the period (Figure 2) may have interfered with fruit growth, thus delaying the onset of maturation in the second production cycle.
Grapes are non-climacteric fruits, that is, their maturation process stops after being harvested, therefore, they should only be harvested when reaching the ideal conditions for consumption (CHAMPA et al., 2014). The sub-phase MT-HA, which comprises the period between maturation and harvest, is a critical period because is when fruit quality is established, being strongly influenced by the climatic conditions and vineyard management. Under the experimental conditions, the first cycle showed longer duration in the MT-HA sub-phase (Table 1). This delay in relation to the same sub- 
phase in the second cycle may be due to the lower observed radiation of $13.71 \mathrm{MJ} . \mathrm{m}^{-2}$ at the end of maturation period (August 2013), whereas in the second cycle, it was 24.0 MJ.m-2 (January 2014) (Figure 2). As vines are heliophilous plants, they demand great solar radiation, so the deficiency of this climatic element can generate problems, mainly in the periods between flowering and maturation
(SMART et al., 1988). According to Pommer (2003), the total hours of sunshine required during the vegetative period is around 1200 to 1400 hours. For a sugar concentration of $24 \%$, about $4 \%$ is formed from plant reserves and $20 \%$ is synthesized in leaves by the action of sunlight during the maturation period of berries.

Figure 2. Monthly averages of solar radiation and rainfall from January 2013 to January 2014. Source: UFERSA Meteorological Station / Rafael Fernandes Experimental Farm.

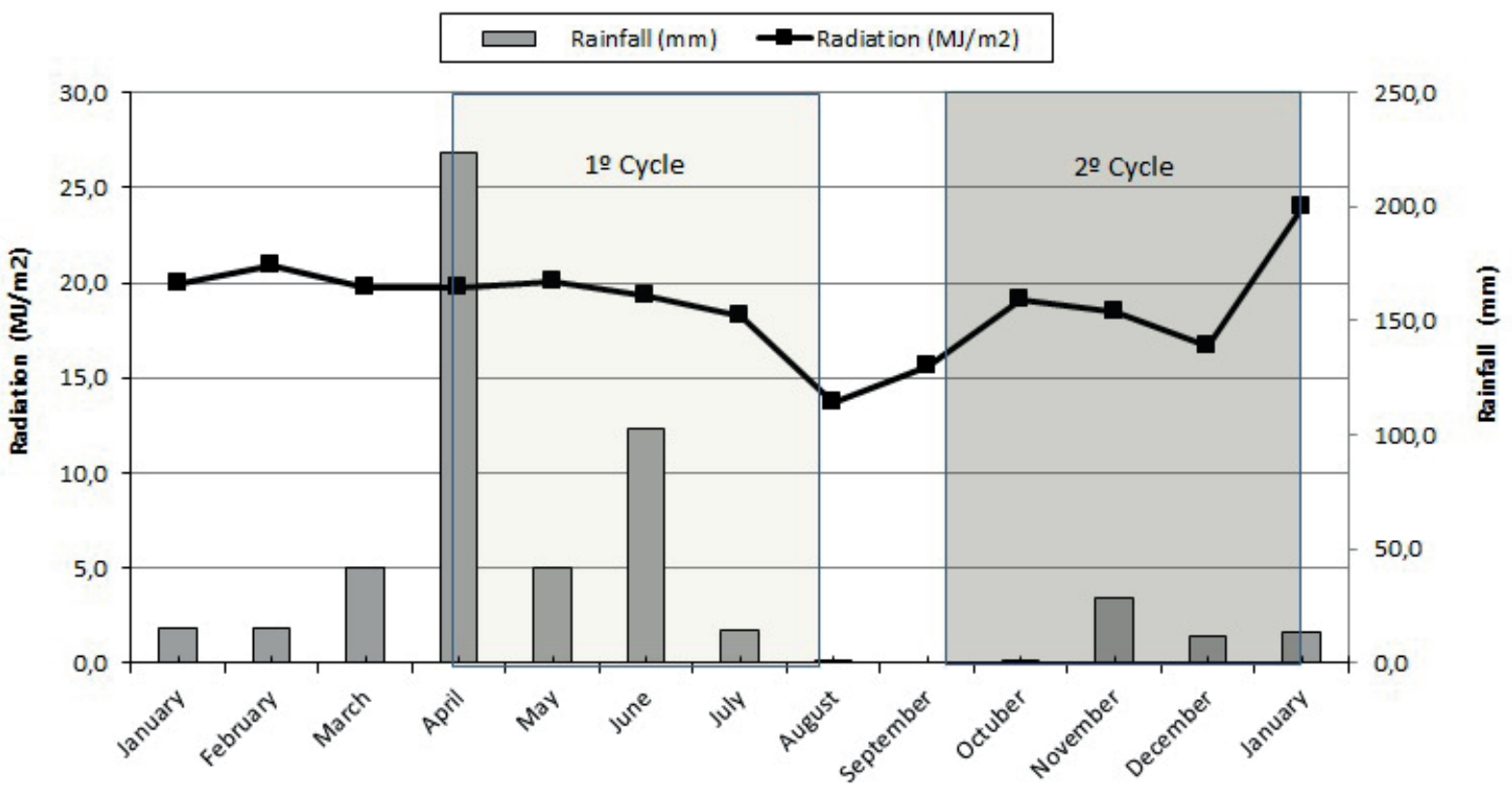

Another factor that may have contributed to the precocity of the second production cycle was the temperature, because despite the few oscillations throughout the year, in the second cycle a discrete increase in mean, maximum, and minimum temperatures was observed, being of $27.2^{\circ} \mathrm{C}$, $33.8^{\circ} \mathrm{C}$, and $22.4^{\circ} \mathrm{C}$, respectively, against a mean of $26.1^{\circ} \mathrm{C}$, a maximum of $32.4^{\circ} \mathrm{C}$ and a minimum of $21.7^{\circ} \mathrm{C}$ in the first cycle (Figure 1). It is worth noting that rainfall records for 2013 were lower than those recorded by Oliveira (2014), with a cumulative of $511.4 \mathrm{~mm}$ in the year, registering in April 223.5 $\mathrm{mm}$, and $00 \mathrm{~mm}$ registered in September (Figure 2).

\section{Biometeorological indexes}

Changes in production and quality of grapes occur due to an interaction between the phenological subphases and local climatic conditions (POMMER, 2003). For Viana (2009), such effects can be explained by interpreting biometeorological indexes such as Degrees Days (DD) and Geslin Heliothermal Index (GHI), and bearing in mind that climatic factors such as temperature and photoperiod are quite important in grape production and quality, and there is a lack of information in the studied region. According to Murakami et al. (2002), the simple extrapolation of these indices to regions other than those for which they were established may lead to 
results that do not correspond to the actual thermal needs of the crop in the new site. For this reason, studies that establish the thermal index of a crop in loco are essential for the adoption of this model in viticulture (MANDELLI, 1984). Table 2 shows the need for Degrees Days during the two productive cycles of 'Itália Melhorada' under the semi-arid conditions of the state of Rio Grande do Norte.

Table 2. Thermal needs (Degrees Days) observed during the phenological stages of the 'Itália Melhorada' grapevine, grown under the semi-arid conditions of the state of Rio Grande do Norte, Brazil.

\begin{tabular}{ccccccccc}
\hline Pruning & \multicolumn{4}{c}{ 1st CYCLE } & \multicolumn{5}{c}{ 2nd CYCLE } \\
\cline { 2 - 9 } & \multicolumn{3}{c|}{$\mathbf{1 0 / 0 4 / 2 0 1 3}$} & & \multicolumn{5}{c}{$\mathbf{2 0 1 3}$} \\
STAGES & DAYS & $\sum$ DD & $\sum$ DAYS & $\sum$ DD (cumulate) & DAYS & $\sum$ DD & $\sum$ DIAS & $\sum$ DD (cumulate) \\
\hline PR-BU & 9 & 108,32 & 9 & 108,32 & 7 & 83,54 & 7 & 83,54 \\
BU-FL & 23 & 257,04 & 32 & 365,36 & 20 & 241,55 & 27 & 325,09 \\
FL-FR & 4 & 43,96 & 36 & 409,32 & 4 & 47,70 & 31 & 372,79 \\
FR-MT & 51 & 543,59 & 87 & 952,91 & 56 & 664,57 & 87 & 1037,36 \\
MT-HA & 28 & 305,36 & 115 & 1258,27 & 24 & 253,14 & 111 & 1290,50 \\
\hline TOTAL & $\mathbf{1 1 5}$ & $\mathbf{1 2 5 8 , 2 7}$ & & & $\mathbf{1 1 1}$ & $\mathbf{1 2 9 0 , 5 0}$ & & \\
\hline
\end{tabular}

PR-BU (Pruning to budding); BU-FL (Budding to flowering); FL-FR (Flowering to fruiting); FR-MT (Fruiting to maturation); MT-HA (Maturation to harvest).

The data show that for the weather conditions in the western Rio Grande do Norte, the sub-phase FRMT, which includes the fruiting period at maturity, was the most demanding in thermal needs in both cycles, presenting a higher value of $\sum \mathrm{DD}$ in the second production cycle (Table 2). This result may have been influenced by the variations of the environmental factors in the two analyzed periods, with higher values of mean, maximum, and minimum temperatures in the second cycle (Figure 1).

It should be noted that there was little variation between the two production cycles under the semiarid conditions of the Rio Grande do Norte, with 115 days for pruning in the first cycle and 111 days in the second cycle (Table 1), accumulating 1258.27 and 1290.50 DD (table 2), respectively, but with few thermal variations during the year (conditions of maximum and minimum temperatures throughout the year without abrupt changes). Therefore, it is noticed that the time of pruning can influence the number of days needed for vines to change the phenological stage. Eventually, the phenological characterization and quantification of thermal units required for vines to complete each phase of the production cycle provide viticulturists with the knowledge of probable dates for harvest, indicating the climatic potential of certain regions for their cultivation (PEDRO JÚNIOR et al., 1993), being a useful tool in the introduction of new cultivars to non-traditional regions such as the semi-arid regions of the state of Rio Grande do Norte in Brazil.

After slight increases in photoperiod and temperature in the second half of the year, a higher HGI value was observed for the PR-BU phase, as shown in table 3 .

According to data presented by Oliveira (2014), the geoviticultural indexes for the semi-arid of Rio Grande do Norte are very similar in the springsummer and the autumn-winter periods. As the photoperiod at latitude $5^{\circ} 11^{\prime} \mathrm{S}$ undergoes little changes throughout the year (only 0.4 hours in the evaluated periods) (Figure 1), the increase in HGI observed for the second production cycle is due to increases in the mean temperatures registered in this period. 
Table 3. Heliothermic Geslin Index (HGI) observed during the phenological stages of the 'Itália Melhorada' grapevine, grown under the semi-arid conditions of the state of Rio Grande do Norte, Brazil.

\begin{tabular}{|c|c|c|c|c|c|c|c|c|c|}
\hline \multirow{3}{*}{$\begin{array}{l}\text { Pruning } \\
\text { STAGES } \\
\end{array}$} & \multicolumn{5}{|c|}{ 1st CYCLE } & \multicolumn{4}{|c|}{ 2nd CYCLE } \\
\hline & \multicolumn{5}{|c|}{$10 / 04 / 2013$} & \multicolumn{4}{|c|}{$25 / 09 / 2013$} \\
\hline & DIAS & HGI & $\sum$ DAYS & $\sum$ HGI & (cumulate) & DIAS & HGI & $\sum$ DAYS & $\sum$ HGI (cumulate) \\
\hline PR-BU & 9 & 29,97 & 9 & & 29,97 & 7 & 22,55 & 7 & 22,55 \\
\hline BU-FL & 23 & 73,02 & 32 & & 102,99 & 20 & 65,81 & 27 & 88,37 \\
\hline FL-FR & 4 & 12,38 & 36 & & 115,371 & 4 & 13,24 & 31 & 101,61 \\
\hline FR-MT & 51 & 153,89 & 87 & & 269,26 & 56 & 187,02 & 87 & 288,63 \\
\hline MT-HA & 28 & 83,58 & 115 & & 352,84 & 24 & 82,54 & 111 & 371,17 \\
\hline TOTAL & 115 & 352,84 & & & & 111 & 371,17 & & \\
\hline
\end{tabular}

PR-BU (Pruning to budding); BU-FL (Budding to flowering); FL-FR (Flowering to fruiting); FR-MT (Fruiting to maturation); MT-HA (Maturation to harvest).

The conditions presented by the analysis of biometeorological indexes for the variety 'Itália Melhorada', under the semi-arid conditions of the Rio Grande do Norte state, reinforce the statements of Oliveira (2014), who said that there is no climatic limitation for grape production in this region in both periods of the year, but there is still need for irrigation to supply the water demand of vines, which can be included in the calendar of management practices, aiming to increase yield in the cycles during the year, as the weather conditions vary little and remain in the range acceptable for viticulture.

\section{Chemical characterization of berries}

According to the analysis of variance, the TSS contents of berries showed no significant differences for blocks, rootstocks, and interaction (rootstock x cycle), but were significant $(\mathrm{P} \leq 0.01)$ for cycles. TTA showed no difference in any of the variation factors, and the TSS / TTA ratio presented significance $(\mathrm{P} \leq 0.05)$ only for cycles.

In both production cycles, the three rootstocks showed no significant differences for the three evaluated traits (TSS, TTA and TSS / TTA) in 'Itália Melhorada' berries (Table 4). Neither did they have an influence on the graft of vines. Similar results were found in 'Isabel' grapes grafted on 'IAC 766 Campinas' and 'IAC 572 Jales' rootstocks in the northern region of Paraná, showing no differences for TSS, TTA, and TSS / TTA characteristics (SATO, et al., 2009).

When comparing both cycles, the berries revealed differences in TSS contents. In the first cycle, these contents, expressed in ${ }^{\circ}$ Brix, were higher (19.24), regardless the rootstock used. This condition may have been favored by the longer period between maturation and harvesting in this period. Furthermore, this increase reflected on a higher TSS / TTA ratio in the same cycle (Table 5). In both cycles, TSS contents were higher than the minimum limit $\left(15^{\circ}\right.$ Brix $)$ required for the marketing of table grapes (CODEVASF, 1994). And the TTA levels obtained in both production cycles $(0.53 \%$, and $0.63 \%)$ were below the recommended maximum limit of $0.75 \%$ (CODEVASF, 1994). The highest values were found in the lower São Francisco region, whose mean was $0.68 \%$ (LEÃO et al., 2011), the slightly higher content of TSS together with the lower of TTA obtained in the first cycle resulted in an improved TSS / TTA ratio, what, together with its accentuated muscat flavor, brings to the variety 'Itália Melhorada' a positive aspect that enhances its potential for cultivation. 
Table 4. Quality traits of berries of 'Itália Melhorada' grapevine in two production cycles, grafted on three rootstocks and grown under the semi-arid conditions of the state of Rio Grande do Norte, Brazil.

\begin{tabular}{ccccc}
\hline \multirow{2}{*}{ Cycle } & \multirow{2}{*}{ Rootstocks } & \multicolumn{3}{c}{ Means (Quality traits) } \\
\cline { 3 - 5 } & & TSS & TTA & TSS / TTA \\
\hline \multirow{2}{*}{$\mathbf{1}$} & 313 & $19,55 \mathrm{a}$ & $0,604 \mathrm{a}$ & $33,77 \mathrm{a}$ \\
& 572 & $19,30 \mathrm{a}$ & $0,508 \mathrm{a}$ & $38,35 \mathrm{a}$ \\
\multirow{2}{*}{$\mathbf{2}$} & 766 & $18,65 \mathrm{a}$ & $0,457 \mathrm{a}$ & $41,23 \mathrm{a}$ \\
& 313 & $16,18 \mathrm{a}$ & $0,693 \mathrm{a}$ & $27,35 \mathrm{a}$ \\
& 572 & $16,43 \mathrm{a}$ & $0,665 \mathrm{a}$ & $25,89 \mathrm{a}$ \\
& 766 & $18,19 \mathrm{a}$ & $0,490 \mathrm{a}$ & $37,34 \mathrm{a}$ \\
\hline
\end{tabular}

TSS: total soluble solids; TTA: titratable total acidity; TSS / TTA: a ratio of total soluble solids and titratable total acidity. Means followed by the same letter do not differ from each other by the Tukey's test ( $p>0.05)$.

Table 5. Quality traits of berries of 'Itália Melhorada' grapevine in two productive cycles and grown under the semiarid conditions of the state of Rio Grande do Norte, Brazil.

\begin{tabular}{cccc}
\hline Cycle & \multicolumn{3}{c}{ Means (Quality traits) } \\
\hline & TSS & TTA & TSS / TTA \\
\hline $\mathbf{1}$ & $19,24 \mathrm{a}$ & $0,535 \mathrm{a}$ & $37,16 \mathrm{a}$ \\
$\mathbf{2}$ & $16,78 \mathrm{~b}$ & $0,632 \mathrm{a}$ & $29,30 \mathrm{~b}$ \\
\hline
\end{tabular}

TSS: total soluble solids; TTA: titratable total acidity; TSS / TTA: a ratio of total soluble solids and titratable total acidity. Means followed by the same letter do not differ from each other by the Tukey's test ( $p>0.05)$.

\section{Conclusions}

The two production cycles of the variety 'Itália Melhorada' during the year are equivalent in terms of the duration of the phenological phases and the quality of fruits, mainly due to the constant conditions of insolation (photoperiod) and temperatures throughout the year.

The behavior of the variety 'Itália Melhorada' on the rootstocks 'IAC 313', 'IAC 572', and 'IAC 766' was equivalent for all the evaluated factors, so they could be used indistinctly.

\section{Acknowledgments}

We are grateful to the Federal Rural Semiarid University (UFERSA) and the Federal Institute of Education, Science and Technology of the State of Pará (IFPA) for their support in conducting this research. To colleagues of the doctoral DINTER / IFPA/UFERSA2013 for the exchange of experiences and collaborations in the accomplishment of this research. Coordination for the Improvement of Higher Education Personnel (CAPES) for granting the doctoral scholarship to the first author.

\section{References}

CHAMPA, W.; GILL, M. I. S.; MAHAJAN, B. V. C.; ARORA, N. K. Postharvest treatment of polyamines maintains quality and extends shelf-life of table grapes (Vitis vinifera L.) cv. Flame Seedless. Posthavest Biology and Technology, Elsevier, v. 91, p. 57-63, may 2014.

CODEVASF. Tecnologia de manejo pré e pós-colheita de uva de mesa. In: . Recomendações para o manejo de colheita e pós-colheita de banana, manga e uva. Brasília, 1994. p. 149-189.

CORREIA FILHO, W. L. F.; MATTOS, A.; BARRETO, N. J. C.; JESUS. E. S.; VALADÃO, C. E. A.; OLIVEIRA, P. T.; SCHMIDT, D. M.; SILVA, B. K. N.; PINHEIRO, 
J. U.; BOLEIRA, A. L.; SANTOS, A. S. Estimativa do balanço hídrico climatológico para o Estado do Rio Grande do Norte. In: CONGRESSO BRASILEIRO DE METEOROLOGIA, 16., 2010, Belém. Anais... Belém, 2010. p. 1-4.

GESLIN, H. Étude des lois de croissance d'une plante en fonction des facteurs du climat température et radiation solaire contribution à l'étude du climat du blé. Paris: Université de Paris, 1944. $116 \mathrm{p}$.

LEÃO, P. C. S.; BRANDÃO, E. O.; GONCALVES, N. P. S. Agronomic and molecular traits of the Italia Muscat clone in São Francisco River Valley. Revista Brasileira de Fruticultura, Jaboticabal, v. 33, n. 1, p. 297-302, 2011.

LORENZ, D. H.; EICHHORN, K. W.; BLEIHOLDER, H.; KLOSE, R.; MEIER, U.; WEBER E. Growth stages of the grapevine. Australian Journal of Grape and Wine Research, Adelaide, v. 1, n. 2, p. 100-110, 1995.

MANDELLI, F. Comportamento fenológico das principais cultivares de Vitis vinifera L. para a região de Bento Gonçalves-RS. 1984. Dissertação (Mestrado em Agrometeorologia) - Escola Superior de Agricultura Luiz de Queiroz, Universidade de São Paulo, Piracicaba.

MURAKAMI, K. R. N.; CARVALHO, A. J. C.; CEREJA, B. S.; BARROS, J. C. S. M.; MARINHO, C. S. Caracterização fenológica da videira cv. Itália (Vitis vinifera L.) sob diferentes épocas de poda na região norte do Estado do Rio de Janeiro. Revista Brasileira de Fruticultura, Jaboticabal, v. 24, n. 3, p. 615-617, 2002.

OLIVEIRA, F. S. Potencial climático da viticultura no Oeste Potiguar. 2014. Dissertação (Mestrado em Ciências, em Fitotecnia) - Departamento de Fitotecnia. Universidade Federal do Semiárido, Mossoró.

PEDRO JÚNIOR, M. J.; SENTELHAS, P. C.; POMMER, C. V. Determinação da temperatura-base, graus-dia e índice biometeorológico para da videira Niagara Rosada. Revista Brasileira de Agrometeorologia, Santa Maria, v. 2, p. 51-56, 1994.

PEDRO JÚNIOR, M. J.; SENTELHAS, P. C.; POMMER, C. V.; MARTINS, F. P.; GALLO, P. B.; SANTOS, R. R.; BOVI, V.; SABINO, J. C. Caracterização fenológica da videira Niagara Rosada em diferentes regiões paulistas. Bragantia, Campinas, v. 52, n. 2, p. 153-160, 1993.

POMMER, C. V. (Ed.) Uva: tecnologia de produção, póscolheita. Porto Alegre: Cinco Continentes, 2003. 775 p.
SATO, A. J.; JUBILEU, B. S.; SANTOS, C. E.; BERTOLUCCI, R.; SILVA, R. A. L.; CARIELO, M.; GUIRAUD, M. C.; FONSECA, I. C. B.; ROBERTO, S. R. Fenologia e demanda térmica das videiras Isabel e Rubea sobre diferentes porta-enxertos na região norte do Paraná. Semina: Ciências Agrárias, Londrina, v. 29, n. 2 , p. 283-292, 2008.

SATO, A. J.; JUBILEU, B. S.; SANTOS, C. E.; BERTOLUCCI, R.; SILVA, R. A. L.; CARIELO, M.; GUIRAUD, M. C.; FONSECA, I. C. B.; ROBERTO, S. R. Evolução da maturação e características físico-químicas de uvas da cultivar Isabel sobre diferentes porta-enxertos na região Norte do Paraná. Semina, Ciências Agrárias, Londrina, v. 30, n. 1, p. 11-20, 2009.

SILVA, J. S. da; SILVA, F. S. B. Considerações sobre agricultura irrigada no Vale do Açu e os impactos sobre o mundo do trabalho. Revista da ABET, João Pessoa, v. 6, n. 1, p. 148-170, 2006.

SMART, R. E.; SMITH, S. M.; WINCHESTER, R. V. Light quality and quantity effects on fruit ripening for cabernet sauvignon. American Journal of Enology and Viticulture, Davis, v. 39, n. 3, p. 250-258, 1988.

STATISTICAL ANALYSIS SYSTEM INSTITUTE SAS INSTITUTE. SAS/STAT User's guide, version 6. $4^{\text {th }}$ ed. Cary: SAS Institute Inc., 1989. v. 1, 943 p.

TEIXEIRA, A. H. de C.; SOUZA, R. A. de, RIBEIRO, P. H. B., REIS, V. C. da S.; SANTOS, M. das G. L. dos. Aptidão agroclimática da cultura da videira no estado da Bahia, Brasil. Revista Brasileira de Engenharia Agrícola e Ambiental, Campina Grande, v. 16, n. 4, p.399-4007, 2012.

VIANA, L. H. Fenologia e quebra de dormência da videira Niagara rosada cultivada na região norte fluminense em diferentes épocas de poda. 2009. Tese (Doutorado em produção vegetal) - Universidade Estadual do Norte Fluminense Darcy Ribeiro, Campos dos Goytacazes.

VILLA NOVA, N. A.; PEDRO JÚNIOR, M. J.; PEREIRA, A. R.; OMETTO, J. C. Estimativa de grausdia acumulados acima de qualquer temperatura base, em função das temperaturas máxima e mínima. Caderno de Ciências da Terra, v. 30, n. 30, p. 1-7, 1972. 